\title{
Editorial
}

\section{Somos todos culpados até que se prove o contrário}

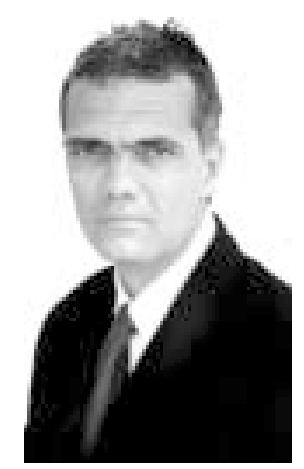

Prof. Dr. Marco Antonio Guimarães da Silva marco@atlanticaedu.com.br

Ao longo dos tempos, as idéias dos grandes pensadores têm influenciado os costumes, a cultura e servido para, em algumas situações, justificar ações políticas. No Direito penal, a filosofia positivista, que encontra no mecanicismo seu esteio principal, influenciou, no passado, o pensar jurídico e acabou justificando, nos regimes políticos de exceção, certos valores para obtenção da culpabilidade dos presumidamente considerados criminosos. Para o bem da humanidade ou, pelo menos, para parte dela, a situação mudou e, mais uma vez, a influência do pensar filosófico, agora Kantiano, promoveu, sob o ponto de vista ético e moral, um resgate do valor da confissão, oferecendo-se ao infrator a oportunidade de reconhecer seus erros e arrepender-se, atenuando, assim, a sua pena.

Caso os equívocos e falta de evidências de nossas investigações científicas fossem considerados crimes, os artigos que publicamos, frutos destas investigações, dariam uma bela materialidade do delito e seriam uma irrefutável confissão.

Haveria, nestes casos, dois tipos de infratores: os crédulos ingênuos e os psendo cognoscitivos. Os primeiros, crédulos ingênuos, são os que se limitam a ler os trabalhos publicados por outros e acreditando, piamente, no que leram, se encarregam de serem vetores multiplicadores das conclusões levantadas no trabalho lido. Se os crédulos ingênuos forem formadores de opinião, a situação se agrava, porque, com certeza, através de suas palestras ou de trabalhos publicados (geralmente sob forma de livros ou de revisão) poderão influenciar com falsas informações um sem números de alunos, ávidos por novos conhecimentos.

Os pseudo cognoscitivos são constituídos por aqueles que efetivamente participam do processo da produção cientifica, executando pesquisas e publicando os seus resultados em periódicos, previamente indexados. Os seus artigos serão lidos pelos crédulos ingênuos e por outros pseudo cognoscitivos à busca de informações para poderem executar seus projetos de pesquisas. Se não tivermos muita cautela, até mesmo excesso de zelo, na interpretação dos resultados expressos nos artigos publicados por estes, estaremos alimentando uma bela cadeia de equívocos.

Mas porque tanto ruído e tanta preocupação com o tema? Haveria tantos equívocos e equivocados nas áreas da investigação e publicação? Há tempos, venho, como já afirmei em outro editorial, exigindo que meus alunos de Especialização (Atlântica Educacional), Mestrado (UCB) e Doutorado (UBA) procedam a respectivamente 25, 75 e 150 análises de artigos, que geram, por sua vez, 100, 300 e 750 páginas de análises criticas dos artigos citados nas referências. Todo e qualquer artigo citado deve passar por analise critica, com nível de exigência circunstanciado ao curso que o aluno esteja fazendo. Depois da análise, os alunos elaboram a pergunta que o autor deveria ter feito

* Editor cientifico de Fisioterapia Brasil Pós Doutorado na UFRJ

Professor do curso de mestrado da UCB 
alunos formulam as hipóteses substantivas e estatísticas, com inserção do valor $\mathrm{p}$ de alfa ou beta, para todos os artigos analisados. Na capacitação desses alunos, feita com analises prévias de artigos, temos observado que somente uma parcela muito pequena de artigos analisados apresenta qualidade. Analisamos publicações em revistas indexadas no país e no exterior e, sem que me causasse surpresas, observamos que publicações em revistas internacionais de grande impacto também apresentam, em sua grande maioria, artigos pouco fundamentados. Um dos exemplos que melhor ilustra o que venho dizendo há anos talvez seja uma meta-analise, publicada em revista indexada no Medline, que nos apresenta o seguinte resultado: de mil novecentos e noventa e seis (1996) artigos publicados sobre lombalgia, se pré selecionou, apenas, doze (12) que atendiam ao mínimo de qualidade exigida para um artigo. Dos doze (12) artigos pré-selecionados, apenas quatro apresentavam os quesitos exigidos para seguirem até o final. Desses quatro (4), apenas dois (2) passaram pelo teste de qualidade total, ou seja, o que diziam podia ser interpretado como expressão da mais pura realidade. Diante deste quadro - a aprovação de apenas dois (2) entre mil novecentos de seis artigos (1996) artigos publicados em revistas de impacto - o que fazer?

Todas as revistas indexadas analisam, através do seu corpo editorial, os artigos que lhe são enviados e, com freqüência, devolvem os artigos aos seus autores para correções. O problema é que as correções não contemplam, obviamente, adequações metodológicas no trabalho já realizado, já que, se assim o fizessem, o autor seria levado a repetir o seu experimento. Em outras situações, o avaliador não esta atento ou, até mesmo, preparado para a detecção dos vieses introduzidos nas pesquisas que geraram os artigos analisados.

A criação e um departamento especializado, em cada editora, que tomasse para si a responsabilidade de analisar metodologicamente as pesquisas contidas em cada trabalho enviado e a exposição destas análises, ao final de cada artigo publicado, poderia ser parte da solução do problema. Restaria saber se o autor concordaria em se expor a tal situação e se as editoras poderiam arcar com a despesa para manutenção da equipe especializada (a margem de lucro das editoras, ao contrário do que se pensa, não é grande).

Bem, talvez no futuro, quem sabe em algum país, os advogados descubram que as equivocadas informações cientificas que passamos para os nossos pares e para a população sejam passiveis de processos e aí nos reste o consolo de reconhecer os nossos erros, nos arrependermos e nos beneficiarmos de uma atenuação de pena. Não nos esquecendo, é claro, de rezarmos uma oração para Kant.

Uma outra sugestão, talvez a mais importante para o momento, seja a de, mais uma vez, evocar o nosso filósofo transcendentalista e interpretar, com rigor, a sua definição de critica: a atitude on capacidade de distinguir entre o verdadeiro e o falso, tendo critérios e razões para tal e não aceitando afirmações de outros sem o seu prévio exame. Quando o assunto é publicação e pesquisa cientifica, cabe duvidarmos de tudo e de todos. Inclusive deste editorial. Afinal, somos todos culpados, até que 